\title{
Diagnosis and Resistance Breeding of Peanut Bud Necrosis Virus
}

D.V.R. Reddy,, T. Satyanarayana, ${ }^{\prime}$ S.L. Dwivedi, ${ }^{1}$ A.S. Ratna, ${ }^{\prime}$ A.A.M. Buiel, ${ }^{2}$ G.V. Ranga Rao, 'S.N. Nigam, ${ }^{\prime}$ R.A. Naidu, ${ }^{\prime}$ H.T. Hsu, ${ }^{3}$ and J.W. Demskit

'Intemational Crops Research Institute for the Semi-Arid Tropics (ICRISAT), Asia Center, Patancheru 502 324, Andhra Pradesh, India; 'Plant Breeding Department, Wageningen Agricultural University, Wageningen, The Netherlands; ${ }^{3} \mathrm{US}$ Department of Agriculture, Agricultural Research Service, Beltsville Agricultural Reseach Center, Beltsville, MD 20705, USA; and ${ }^{4}$ Department of Plant Pathology, Georgia Experiment Station, Griffin, GA 30223, USA

The occurrence of peanut bud necrosis (PBN) disease in India was first reported in 1968. The high incidence of PBN disease during the $1960 \mathrm{~s}^{\circ}$ coincided with largescale imports of the peanut cultivars Asiria Mwitundae

of which are highly susceptible to PBN. Since then, a number of reports have been published in India describing bud necrosis under at least seven different names (Reddy 1988). Crop losses due to PBN have been estimated at USD89 million per year in India during 1976-1986. The disease is also currently recognized as economically important in Nepal (Sharma 1996), in Sri Lanka, and in Thailand (Wongkaew 1995).

The causal agent of PBN was originally reported as tomato spotted wilt virus (TSWV) (Ghanekar et al. 1979). Since then, methods to purify the causal virus of PBN have been developed, which facilitated the production of good quality antisera. On the basis of serological relationships, some physicochemical properties, and thrips transmission, it was shown that the causal virus of PBN'in India was a distinct tospovirus that was named peanut bud necrosis virus (PBNV, Reddy et al. 1992). These results were subsequently confirmed by Adam et al. (1993). Later, monoclonal antibodies (MAbs) have been produced against the nucleocapsid $(N)$ protein of PBNV (Poul et al. 1992). Antibodies from nine clones failed to react with a TSWV-lettuce (TSWV-L) isolate and with an impatiens necrotic spot virus (INSV) by triple-antibody sandwich enzyme-linked immunosorbent assay (TAS-ELISA) (coating of PBNV polyclonal antiserum, addition of antigen followed by addition of MAbs and antimouse IgGs conjugated to alkaline phosphatase). Of 16 MAbs produced against TSWV-L (Hsu et al. 1990), 12 H5 Al (f), 12 H5 H5 (l), 
and $10 \mathrm{C}_{2} \mathrm{FP}$ (n) reacted with TSWV-L, but none reacted with PBNV in TAS-ELISA. Because PBNV and TSWV-L MAbs did not react in western blots it was not possible to test the specificity of the MAbs to glycoproteins G1 and G2 or N proteins.

Recently, the complete nucleotide sequence of the S RNA of PBNV was determined (Satyanarayana et al. 1996a) and shown to be 3057 nucleotides in length. The gene that codes for the N protein was cloned in Escherichia coli using the $\mathrm{pET} 15 \mathrm{~b}$ as the vector. The molecular weight of the expressed protein was $31.5 \mathrm{kDa}$, which corresponds with the N protein of PBNV. Protein extracted from polyacrylamide gels was used to produce polyclonal antiserum in rabbits. The serum reacted only with PBNV and not with TSWV-L or INSV. Furthermore, PBNV was shown to be transmitted efficiently by Thrips palmi (Vijayalakshmi 1994)

Progress has been made in the identification of sources of resistance. Groundnut gerniplasms conserved at the ICRISAT Asia Center (IAC) from a global collection have been screened systematically under field conditions during times of maximum disease pressure (early June for Indo-Gangetic plains and mid-July for the rest of India) using widely spaced plants ( $20 \mathrm{~cm}$ in the row and $75 \mathrm{~cm}$ between rows). PBNV incidence exceeded $80 \%$ in susceptible controls. The genotypes belonging to $A$. hypogaea ssp. fastigiata were more susceptible than those belonging to ssp. hypogaea. Genotypes that showed consistently low PBN incidence (about 20\% that of susceptible controls) were chosen for subsequent field screening. These were ICG numbers $848,851,852,862,869,885,2271,2306,2307,2323,2741,3042$, 3806, 3873, 5030, 5024, 5043; 5044, 6135, 6317, 6323, 7676, and 7892. All belonged to ssp. hypogaea (Dwivedi et al. 1995). These genotypes vvere used in a crossing program with the aim of improving yield quality, and adaptability to regions in India where PBNV was known to be endemic. The progenies were tested under field conditions at different generations. Advanced breeding lines that showed field resistance ( $\leq 20 \%$ of the incidence of susceptible controls) were evaluated for $T$. palmi resistance in the field and for virus resistance by mechanical sap inoculations in the laboratory. Resistance to thrips was evaluated on a 1-9 scale (1 highly resistant to 9 highly susceptible). Lines that showed vector resistance (thrips injury score of less than 4.0) were then evaluated for their PDNV reactions following mechanical inoculation with $10^{-1}$ and $10^{-2}$ dilutions of extracts from infected peanut leaflets (Table 1).

The genotpes that showe nidd-Jesistance als had iEctor resistance. It appears that genotypes ICGV 86598 and 86031 express internediate levels of virus

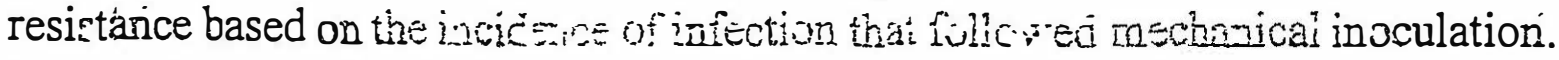
The majority of the field-resisiart varieties were rasinu-buration types. Forty genotyres that were identified at LAC. to have field resistance were tested in four kigh inderice steis for PBN to evaluste the efie riveness of the resistance in 
Table 1. Perfornance of selected peanut lines showing field resistance to PBN.

\begin{tabular}{|c|c|c|c|c|}
\hline \multirow[b]{2}{*}{$\begin{array}{c}\text { Lines } \\
(\mathrm{ICGV}) \\
\end{array}$} & \multirow[b]{2}{*}{$\begin{array}{c}\text { Thrips } \\
\text { injury scale }\end{array}$} & \multicolumn{2}{|c|}{ PBN incidence (\%) } & \multirow[b]{2}{*}{$\begin{array}{l}\text { Pod yield } \\
(\mathrm{t} / \mathrm{ha})^{\mathrm{c}}\end{array}$} \\
\hline & & $\begin{array}{c}\text { Mechanical } \\
\text { inoculation } \\
\text { (10² dilutions) }\end{array}$ & Field $^{\mathrm{b}}$ & \\
\hline 91249 & 4.0 & 70 & 17 & 2.53 \\
\hline 91177 & 4.0 & 100 & 14 & 2.55 \\
\hline 86388 & 5.0 & 46 & 18 & 2.04 \\
\hline $86031^{d}$ & 4.5 & 50 & 12 & 2.67 \\
\hline ЛL $24^{\mathrm{e}}$ & 7.5 & 100 & 58 & 1.68 \\
\hline
\end{tabular}

${ }^{a}$ On 1-9 scale (1 highly resistant; $2-3$ resistant; $4-5$ moderately resistant; $6-7$ susceptible; $8-9$ highly susceptible).

${ }^{b}$ Average of 3-6 locations.

. Data from three seasons: rainy 1993; post-rainy 1993-1994; and rainy 1994.

${ }^{\mathrm{d}}$ Field-resistant control.

${ }^{e}$ Field-susceptible control.

different locations. Interestingly, the performance of all the genotypes across environments was similar. It is now apparent that if variability existed within PBNV at the time of this study,

The incidence of PBNV varied considerably among locations, and to a lesser extent among years within the same location (Buiel et al. 1995).

A great deal of success has been achieved in incorporating resistance to tospoviruses into crops by using oide or more of viral genes (Peters et al. 1995). In this connection, $S$ and M RNA of PBNV has been fully sequenced (Satyanarayana et al. 1996b) and genes with potential for use in transformation have been identified. Nevertheless, exploitation of these genes awaits efficient transformation and regeneration protocols for peanut.

Submitted as Journal Article No. CP 1056 by ICRISAT.

Adam, G., Yeh, S.D., Reddy, D.V.R., and Green, S.K. 1993. The serological comparison of tospovirus isolates from Taiwan and India with Impatiens necrotic spot virus and different tomato spotted wilt virus isolates. Arch. Virol. 130, 237-250.

Buiel, A.A.M., Dwivedi, S.L., Prasad, M.V.R., Singh, A.B., Dhammaraj, P.S., and Parlevliet, J.E. 1995. Multi-environment testing for reduced incidence of peanut bud necrosis disease in India. in: Recent stridies on peanut bud necrosis disease. A.A.M. Buiel, J.E. Parlevliet, and J.A. Levn, Eds. ICRISAT, india, 47-54.

Dwivedi, S.L., Nigam, S.N., Reddy, D.V.R., Reddy, A.S., and Ranga Rao, G.V. 1995. Progress in breedirs groindnut varieties resistant to peanut bud necrosis 
virus and its vector. In: Recent studies on peanut bud necrosis disease: A.A.M. Buiel, J.E. Parlevliet, and J.M. Lenn, eds., ICRISAT, India, 35-40.

Ghanekar, A.M., Reddy, D.V.R., Iizuka, N., Amin, P.W., and Gibbons, R.W. 1979

Bud necrosis of groundnut (Arachis hypogaea) in India caused by tomato spotted wilt virus. Ann. Appl. Biol. 93, 173-179.

Hsu, H.T., Wang, 'Y.C., Lawson, R.H., Wang, M. and Gonsalves, D. 1990. Splenocytes of mice with induced immunological tolerance to plant antigens for construction of hybridomas secreeting tomato spotted wilt virus-specific antibodies. Phytopathology, 80, 158-162.

Peters, D., Prins, M., and Goldbach, R. 1995. Génome organization of tospoviruses and the potential of some of their genes to develop transgenic resistance in plants. Proc. Working Group on Groundnut Viruses in the Asia-Pacific Region. ICRISAT, India (in press).

Poul, F., Ratna, A.S., and Reddy, D.V.R. 1992. Production of monoclonal antibodies to bud necrosis virus. International Arachis Newsletter, 12, 12-14.

Reddy, D.V.R. 1988. Groundnut virus diseases occurring in India. Indian Council Agr. Res., India, 508-525.

Reddy,D.V.R., Ratna, A.S., Sudarshana, M.R., Poul, F., and Kiran Kumar, F. 1992. Serological relationships and purification of bud necrosis virus, a tospovirus occurring in peanut (Arachis hypogaea L.) in India. Ann. Appl. Biol. 120, 279-286.

Satyanarayana, T., Niitchell, S.E., Reddy, D.V.R., Brown, S., Kresovich, S., Jarret, R., Naidu, RA., and Demski, J.W. 1096a. Peanut bud necrosis tospovirus sRNA: complete nucleotide sequence, genome organization and homology to other tospovirises. Arch. Virol. 141, 85-98.

Satyanarayana, T., Mitchell, S.E., Reddy, D.V.R., Brown, S., Kresovich, S., Jarret, R., Naidu, R.A., Gowda, S., and Demski, J.W. 1996b. Peanut bud necrosis virus: Purification of nucleocapsids and sequence homology of nucleocapsid protein and glycoprotein precursor with other tospoviruses. Acta Hort. (this issue).

Sharma, B.P. 1996. Current status of legume viruses with special reference to groundnut viruses in Nepal. Proc. Working Group Meeting on Viruses of Groundnut in the Asia-Pacific Region. ICRISAT, India (in press).

Vijayalakshmi, K. 1994. Transmission and ecology of Thrips palmi kamy, the vector of peanut bed necrosis virus. $\mathrm{PbD}$ Thesis, Audhra Pradesh Agr. Univ., Hyderabad, India.

Wongkaew, S. 1995. Peanut bud necrosis disease in Thailand. In: Recent studies on peanut bud necrosis disease. A.A.M. Buiel, J.E. Parlevliet, and J.M. Lenn, eds., ICRISAT, India, 55. 